\title{
Investigating the Influence of Organizational Factors on Supply Chain Awareness
}

\author{
Ramakrishna Yanamandra \\ Skyline University College, \\ University City of Sharjah - P.O. Box 1797 - Sharjah, UAE \\ Email: ramakrishna@skylineuniversity.ac.ae
}

\begin{abstract}
Organizations have improved customer service and witnessed a reduction in their overall costs of operations by implementing supply chain (SC) practices. But many research studies reveal that only the large size companies due to their size and financial ability to invest in innovative practices have been able to visualize these benefits of SCM and many medium size manufacturing companies (MSMCs) have not yet been able to fully reap the positive outcomes of SCM. Organizational factors like size, experience, capital investment and product variety influence this degree of SC awareness and adoption. Studies related to this aspect of SCM are found to be less focused on MSMCs. This paper therefore studies empirically the influence of these organizational factors the degree of SC awareness, identifies the SC practices and analyzes whether degree of SC awareness has any influence on the degree of adoption of SC practices in MSMCs. The results of this study provide value to the SC practitioners and researchers.
\end{abstract}

Keywords: supply chain strategies and practices, supply chain awareness, degree of adoption, medium sized manufacturing companies, information sharing

\section{INTRODUCTION}

Supply Chain Management (SCM) has become an important strategy in the recent past for business organizations in achieving competitive advantage (Gorane and Ravikant, 2016; Wisner et al., 2016; Coyle et al., 2017; Kwak et al., 2018). Defined as management of upstream and downstream relationships with suppliers and customers to deliver superior customer value at a lesser cost to the chain as a whole (Ellram and Cooper, 1990; Salam et al., 2016), implementation of SCM practices is found to decrease costs and improve profits in business organizations (Al-Shboul et al., 2017).

SCM is found to influence the initiatives related to sustainability and scalability in many large size organizations, both in manufacturing and service sector and enable organizations to enhance their competitive advantage (Quayle, 2003; Martin and Matthias, 2011; Kwak et al., 2018; Hariharan et al., 2019). At the same time, several authors opined that SCM can also play a similar role in medium size manufacturing companies (MSMCs) by plugging many gaps related to communication among the members of the chain, resulting in a decrease of overall costs (James and Ashraful, 1997; Al-Shboul et al., 2017), enabling an innovation culture (Didonet and Diaz, 2012) and providing competitive advantage (Alhourani and Saxena, 2014; Thoo et al., 2017; Kwak et al. 2018).

But, inspite of its benefits, studies reveal that the practices of SCM are mostly limited to mainly the large scale manufacturing and service sector companies (Paul and Jeong, 2006; Kot et al., 2018). Its implementation in MSMCs is not as similar to the one in large scale companies (Stonkute, 2015; Ramakrishna, 2016; Kot et al., 2018). MSMCs face challenges and issues such as lack of complete awareness, lack of interest and expertise, confusion over which practices of SCM have to be implemented, scarcity of funds, lack of innovation and myths about benefits of implementation of SCM (Rajesh et al., 2008; Stonkute, 2015; Kot et al., 2018). They focus more on mere survival of their businesses rather on understanding and implementing concepts like SCM for long-term survival and sustainability (Thoo et al., 2017; Usman and Koseoglu, 2019).

It is found that implementation of SCM depends on an important organizational factor like Supply Chain Awareness (SCA). This awareness, in turn is significantly influenced by the size of the organization (Youqin et al., 2013; Juliana et al., 2013; Mishra, 2019), capital investment, length of existence of the company (experience), and product variety (Afande et al., 2015; Huddiniah and ER, 2019). Moreover, the degree of SCA is found to differ across diverse industry sectors of MSMCs (Kwan, 1999; Ulusoy, 2003; Jharkharia and Shankar, 2006; Gorane and Ravikant, 2016).

In order to analyze the adoption of SCM in MSMCs, it is essential to understand the degree of SCA and various organizational factors influencing its implementation (Youqin et al., 2013) and this awareness is crucial as it enables the managers to understand the significance of SCM in achieving competitive advantage through innovative strategies (Kwak et al. 2018; Mishra, 2019). Increased degree of SCA influences top management's commitment towards SCM (Larry and Richard, 1996; Pagell and Krause, 2004; Hariharan et al., 2019) and improves its willingness and interest to implement SCM by investing money through the allocation of an exclusive budget for various initiatives related to SCM (Higginson and Alam, 1997).

Studies related to SCA and its influence on degree of adoption of SC practices and strategies in MSMCs are found to be very limited, inspite of many studies related to SCM in MSMCs (Arend and Wisner, 2005; Valand and Heides, 2007; Thoo et al., 2017). Moreover, number of empirical studies related to SCA and its influence on adoption of SCM practices are limited (Niranjan, 2012). Influence of 
organizational factors like size, experience, capital investment and product variety on the degree of SC awareness have not been studied in MSMCs in detail. Therefore, considering this research gap, the present research identifies the influence of organizational factors on the degree of SCA and in turn studies the influence of this SCA on the degree of adoption of supply chain practices in MSMCs. The organizational factors considered for this purpose are size, experience, capital investment and product variety, based on a systematic literature review. Also, the later part of the paper focuses on identifying the SC practices in MSMCs and the influence of degree of SC awareness on the adoption of SC practices, a necessity also identified by Gorane and Ravikant (2016).

The study attempts to answer the following three research questions based on the above discussion.

- $\quad \boldsymbol{R Q 1}$. Does the degree of SCA differs across different industry sectors of MSMCs?

- $\boldsymbol{R Q 2}$. Do organizational factors like size of the organization (in terms of number of employees), capital investment, length of existence of company (in terms of number of years since its establishment) and product variety of MSMCs influence the degree of SCA?

- $\quad \boldsymbol{R Q 3}$. Does the degree of SCA influence the degree of adoption of SCM practices in MSMCs?

These research questions are addressed by validating six relevant hypotheses developed based on a literature review.

This paper aims to provide new insights to the supply chain managers of MSMCs through an analysis of results obtained through an empirical survey conducted in four leading MSMC industry sectors such as engineering, electrical and electronics, chemical and pharmaceutical sector. The Directory of Industries of an authorized local industries' body in India has been used for this purpose.

The next section of the paper presents a systematic literature review conducted to identify the organizational factors and their influence on the degree of SCA. Based on this literature review, a research framework with six research hypotheses is developed. At the end, the results are discussed to arrive at the conclusions and implications for future research.

\section{THEORETICAL BACKGROUND AND HYPOTHESES}

A review of literature reveals that there are many definitions of SCM (Stock and Boyer, 2009). Due to its wide and diverse nature, the researchers have not been able to arrive at a consensus (Mentzer, 2001; Burgess et al., 2006) on a single definition of it. This ambiguity may influence its adoption in MSMCs too (Thoo et al., 2017).

Ellram and Cooper (1990), defined SCM as a management of upstream and downstream relationships with suppliers and customers to deliver superior customer value at a lesser cost to the chain as a whole. Council of Supply Chain Management Professional (CSCMP, 2019) defines SCM as a process which encompasses the planning and management of all activities involved in sourcing and procurement, conversion, and all logistics management activities. Importantly, it also includes coordination and collaboration with channel partners, which can be suppliers, intermediaries, third party service providers, and customers. In essence, supply chain management integrates supply and demand management within and across companies.

The definition of SCM took different forms based on different theories related to other disciplines of management. For instance, definitions of SCM originated from the popular theory of Resource-Based View (RBV) were mostly focused on assets and resources of organizations with special reference to manufacturing sector. Therefore, this view is considered for literature review of the present study. Halldorsson et al., (2007) is of the view that there is no such thing as "unified theory of SCM". Different situations of managers and organizations lead to the selection of a convenient definition of SCM and then it is complemented with one or several of the other theoretical perspectives.

The resources of SCM using RBV approach are found to contribute to the overall efficiency of organization (Lewis, 2000; Pandza et al., 2003; Rungtusanatham et al., 2003; Yang et al., 2019). These resources are related to different functional areas of the organization (Grant, 1991; Prahalad and Hamel, 1990). An organization's supply chain is influenced by its core competencies achieved through these resources and thus it secures the competitive advantage. Based on the changes in the business environment, these resources enable the organizations to enhance their competencies by quickly reacting to these changes (Prahalad and Hamel, 1990; Halldorsoon et al., 2007; Yang et al., 2019)

Most of the practices of SCM were dealt from the perspective of large size manufacturing companies and not by focusing on MSMCs specifically (Valand and Heides, 2007; Thoo et al., 2017). This paper fills this gap in the body of knowledge and identifies SCM practices which are adopted and implemented by specifically by MSMCs.

SCM is found to play a very vital role in sustainability and scalability of MSMCs and it has the potential to improve their competitive advantage (Quayle, 2003; Martin and Matthias, 2011; Kwak et al., 2018). Importance of SCM in MSMCs can also be attributed to several factors like opportunities provided by globalization, vertical integration of firm's activities, minimization of international trade barriers, availability of abundant information due to the tremendous growth of information systems and technology, and growing awareness towards environmental protection (Bala, 2007). Sharing of information is needed in this increased global network of organizations with mutual trust as the main focal area in business (Ahlstedt and Hameri, 2004).

Therefore, effective adoption and implementation of SCM can resolve many issues in MSMCs related to communication and it has the ability to decrease overall costs (Rouhollah and Shivraj, 2011; Al-Shboul et al., 2017). Aspects such as, supplier relationship management, development of high-quality products and services, sharing of information across the SC entities are found to be adopted by some of the MSMCs (Higginson and Alam, 1997; Gorane and Ravikant, 2016) and SC strategy, SC integration, inventory management and information technology are found to be the four major pillars of SCM in some other MSMCs (Sahay and Mohan, 2003; Li et al., 2017).

However, many authors opined that the degree of adoption of SCM in MSMCs is at a minimum level as these 
companies encounter challenges in its implementation (Stonkute, 2015; Usman and Koseoglu, 2019). Some of these are inappropriate clarity, lack of top management support and commitment (Hariharan et al., 2019), a traditional and conservative approach by focusing only on localized benefits, outdated technology, lack of expert supply chain manpower, scarcity of financial resources, and inadequate support of government (Pagell and Krause, 2004; Thakkar et al, 2009; Juliana, 2013; Kot et al., 2018). Also, MSMCs are found to be at disadvantageous side as they can't adapt quickly to the dynamic nature of globalization due their limited capacity to bargain with the members of the chain (Defee, 2006; Usman and Koseoglu, 2019).

Another important reason for low levels of $\mathrm{SC}$ implementation in MSMCs may be that many authors focused on SCM practices of large firms, while MSMCs are treated mostly from the viewpoint of larger firms (Lambert and Cooper, 2000; Chopra and Meindl, 2013). Also, authors did not focus on the applicability of SCM practices which are appropriate for large size organizations equally in case of MSMCs (Chen et al., 2004; Sahay et al., 2006; Paul and Jeong, 2006; Kot et al., 2018). Therefore, there is a clear need to identify and establish the SCM practices adopted by MSMCs exclusively (Gorane and Ravikant, 2016).

Lack of top management support (Maguire and Magrys, 2001; Pagell and Krause, 2004; Hariharan et al., 2019) and lack of long-term vision (Gunasekaran et al., 1996; Thoo et al., 2017) are also found to be the main reasons for moderate implementation of SCM in SMEs. This emphasizes that the SCM adoption can improve in MSMCs if the top managements are aware of SCM, which is known as Supply Chain Awareness (SCA) and provide direction for implementing the SCM practices at all levels (Premkumar and Ramamurthy, 1995; Teo et al., 2004; Juliana et al., 2013).

SCA is defined as the degree to which an individual and organization completely understands all the aspects of the SCM (Forman and Lipper, 2005). It is found that managers with high levels of SCA tend to support the implementation of SC practices and they focus on integration of all the functions to improve the overall organizational performance. Whereas managers with less or little SCA may not focus on overall SC integration and would only limit their attention to their individual firms, defeating the objective of SCM (Forman and Lipper, 2005; Paik et al., 2011). The degree of SCA is found to vary based on type of industry sector of MSMC (Kwan, 1999; Ulusoy, 2003; Jharkharia and Shankar, 2006; Gorane and Ravikant, 2016). It is essential to understand the degree of SCA and the organizational factors influencing it (Youqin et al., 2013) to understand the overall scenario of SC adoption in MSMCs.

Therefore, to identify this influence the following hypothesis is developed.

H1: Degree of SC awareness differs across different industry sectors of MSMCs.

SCA is also found to be influenced by several organizational factors. Among these factors, size of the business, measured in terms of number of full-time employees, is found to significantly influence the degree of supply chain awareness (Paik et al., 2011; Youqin et al., 2013; Juliana et al., 2013). Therefore, in order to investigate the influence of this organizational factor, i.e., size of the business, on SCA, the following hypothesis is developed.

\section{H2: Size of MSMC has a positive influence on the degree of SC awareness.}

The other organizational factors which are found to influence SCA are capital investment, product variety (Afande et al., 2015; Huddiniah and ER, 2019) and length of existence of the company (measured as the number of years of existence of MSMC since its establishment) Juliana et al. (2013). Therefore, in order to investigate the influence these organizational factors on SCA, the following three hypotheses are developed.

\section{H3: Capital Investment of MSMC has a positive influence on degree of SC awareness.}

H4: Product Variety has a positive influence on degree of awareness of SCM.

H5: Length of Existence of the company has a positive influence on degree of SC awareness.

Validation of these hypotheses lead to the answers for first two research questions mentioned in the earlier section of the paper.

Degree of SCA significantly influences the adoption of supply chain practices in MSMCs. It is also crucial in achieving competitive advantage through innovative strategies related to SCM (Mishra, 2019). Degree of SCA influences top management's commitment towards SCM (Larry and Richard, 1996; Hariharan et al., 2019), willingness and interest to implement SCM and investment and allocation of an exclusive budget for the initiatives related to SCM (Higginson and Alam, 1997). As indicated by Lepoutre and Heene (2006), small and large businesses basically possess different resources and capabilities such as: financial turnover; assets, market share; numbers employed; and ownership. They have less access to resources and are less powerful than their larger counterparts (Juliana et al., 2013). SCM provides positive outcomes only when the practices associated with it are properly and effectively adopted and implemented (Metilda and Vivekanandan, 2011). In order to understand the degree of adoption of supply chain, it is essential to identify and investigate practices which are considered to be part of supply chain.

Supply chain practices (SCPs) range from diverse initiatives and activities of an organization and they are defined as a set of activities adopted by an organization to integrate the upstream and downstream processes of supply chain (Li et al., 2006). Implementation of these practices results in reduction of costs associated with inventory and build mutual coordination among the members of SC (Sujatha, 2011; Al-Shboul et al., 2017). But in spite of its benefits, SCPs are not properly understood by organizations (Cook et al., 2011). There is no generalized consensus on what exactly is included in SCPs (Harrison et al., 2002), though it is mentioned that SC strategy should be a part of business strategy by many authors. Moreover, the scenario of SCM implementation in MSMCs is different when 
compared to that of large size companies in manufacturing sector (Rajesh et al., 2008). Therefore, this section of literature review identifies which practices of MSMCs are considered as part of SCM practices.

Integration of supply chain for real time information sharing, quality of information shared (Hariharan et al., 2019; Mathu, 2019), Just-in-Time (JIT), production and quick delivery of product, supplier relationship management, customer relationship management, and postponement are identified as strategies and practices of upstream and downstream areas of SCM by Tan et al., (2002). Sahay and Mohan, (2003) found a linkage between SC practices and overall business strategy in MSMCs and identified that providing customer service, managing demand and inventory, order processing and fulfilment management system, manufacturing technology and process, development of product, transportation and logistics management, management of distribution, export and import management, and warehouse management system as major SC practices and also found that there is no major difference in their implementation in different industry sectors of MSMCs. Information sharing with suppliers, early supplier involvement (ESI), creating awareness among suppliers by providing training to them and integrating the activities of suppliers and distributors are identified as practices of SCM (Higginson and Alam, 1997; Hariharan et al., 2019; Mathu, 2019). Supplier development, achieved through information sharing with the suppliers is identified as one of the important SC practice (Mentzer, 2001; Gorane and Ravikant, 2016). This practice is enabled through internet (Frohlich and Westbrook, 2002; Mishra, 2019) to achieve reduced inventory levels (Kwan, 1999; Hariharan et al., 2019).

Another most popular SC practice is supply chain integration which is achieved through internal integration (coordination among the various management functions) and external integration which is achieved through the coordination of activities related to suppliers, distributors, dealers, retailers, warehouse managers and customers (Ellram 1995; Thakkar et al., 2012; Li et al., 2017; Khan and Wisner, 2019; Porter, 2019). This integration is also achieved through supply contracts between the buyer and supplier in areas of pricing, volume, lead time, quality, and product return policies. Supply contracts are also among the popular SC practices (Wang, 2002; Simchi Levi and Kaminsky, 2009; Li et al., 2017).

Strategic alliances, another key SC practice, is achieved through supply contracts to obtain better supply chain outcomes (Dyer and Singh, 1998; Chen et al., 2004; Defee, 2006; Cousins et al., 2008; Zhaofu and Xiaolong, 2019). Collaborative Planning, Forecasting and Research (CPFR), a web-based technique which improves the forecasting of demand and increases the smooth flow of SC activities (Udin et al., 2006; Chopra and Meindl, 2013; Singhry and Rahman, 2019) is another highly popular SC practice. Enterprise Resource Planning (ERP), one more practice of SC is found to be extensively used in areas like logistics and transportation, vendor, and order management along with Material Requirement Planning (MRP) and Warehouse Management System (WMS) to improve operational efficiency and productivity (Gorane and Ravikant, 2016; Baruffaldi et al., 2019). ERP can be successfully implemented if four critical success factors such as education and training, strategic decision-making, communication, and business process alignment will be successful if user's perspective is considered (Reitsma et al., 2018).

Similarly, Radio frequency identification (RFID) (Koh et al., 2007; Ting and Tsang, 2012; Gorane and Ravi Kant, 2016), e-procurement (Koh et al., 2007; Mathu, 2019), Electronic Data Interchange (EDI) (Atul et al., 2010; Atnafu and Balda, 2018), Vendor Managed Inventory (VMI) (Holweg et al., 2005; Gorane and Ravi Kant, 2016 ), Outsourcing and Subcontracting (Na, 2011; Kabiraj and Sinha, 2017) are also widely mentioned as SC practices. Practices related to lean manufacturing and skill development of employees, especially the behavioral soft skills such as communication and initiative skills to implement SCM are also considered as SC practices (Burgess et al., 2006; Lewis, 2000; Ghosh, 2012; Bak et al., 2019). An integrated lean supply chain framework was developed by Chakraborty and Gonzalez (2018) considering technology integration and supplier relationship management and lean orientation to improve the patient care quality which is also relevant for SMEs.

Therefore, based on the above discussion, the paper finalizes nineteen practices as a part of supply chain practices. These are, Information Sharing with Suppliers (ISS), Training the Suppliers (TS), Early Supplier Involvement (ESI), Supply Chain Integration (SCI), Supply Contracts (SC), Strategic Alliances (SA), Collaborative Planning, Forecasting and Replenishment (CPFR), Enterprise Resource Planning (ERP), Material Requirement Planning (MRP), Warehouse Management System (WMS), Radio Frequency Identification (RFID), e-Procurement (EP), Electronic Data Interchange (EDI), Vendor Managed Inventory (VMI), Just-in-Time (JIT), Outsourcing (OS), Subcontracting (SC), Lean Manufacturing Practices (LMP), and Developing Supply Chain Skills among Employees (DSCSAE).

Therefore, in order to validate the influence of SCA on the degree of adoption of SCM in MSMCs, hypothesis (H6) is developed as below.

H6: Degree of SC awareness has a positive influence on the degree of adoption of SCM

Thus, the study investigates initially the variation in the degree of SCA across different industry sectors, then it investigates the influence of four organizational factors like size, capital investment, length of existence and product variety on the degree of SCA and finally, it investigates the influence of degree of SCA on degree of adoption of supply chain management practices in medium sized manufacturing companies (MSMCs). Validation of H6 answered the third research question proposed.

\section{METHODOLOGY}

An empirical study was conducted in MSMCs across four sectors, electrical and electronics, engineering, chemical and pharmaceutical sectors in the industrial clusters in India from May, 2019 to Dec, 2019. The framework of hypotheses is presented in Figure 1. 


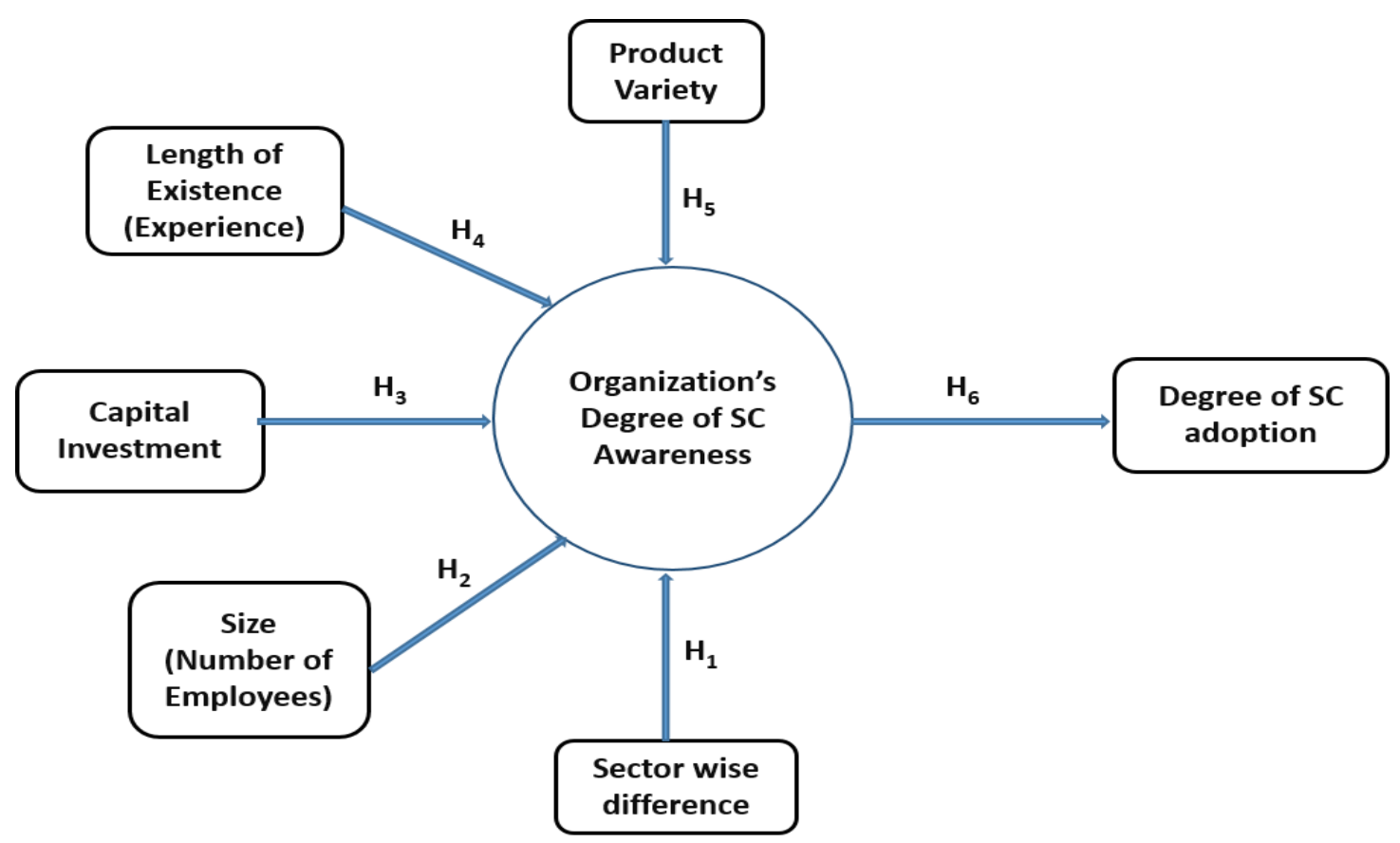

Figure 1 Framework of Hypotheses

A sample of MSMCs was selected using Proportionate Stratified Random Sampling technique. The most popular industry membership directory of Federation of Telangana and Andhra Pradesh Chamber of Commerce and Industries (FTAPPCCI) was considered as the basis for selection of MSMCs whose capital investment is between 5 crores to less than or equal to ten crore Indian rupees as per the definition of MSMEs by Government of India. The directory has a total membership of $388 \mathrm{MSMCs}$ as per this definition. Out of them, a total of 276 companies in the selected four sectors were found to be meeting the capital investment criteria. Fifty percent of MSMCs from each industry sector mentioned above were considered as a sample of study, which is fairly a good representation of the total population. Therefore, the total sample size is $138 \mathrm{MSMCs}$, out of the eligible 276. Among these, 23 belong to electrical/electronic sector, 59 belong to engineering sector, 27 belong to chemical and 29 belong to pharmaceutical sector. The Primary Data was collected using a survey instrument (Questionnaire). The questionnaire consisted questions related to sector of company, number of employees (size), length of existence (experience), capital investment, type of product manufactured (industrial or consumer), number of products manufactured (product variety), organization's awareness about SCM, investment in SCM related aspects by the top management (Pagell and Krause, 2004; Hariharan et al., 2019), role of SCM in reducing costs in the first and second sections.

In the third section of the questionnaire, nineteen SC practices were listed. The SC managers were asked to provide their opinion on the degree of adoption of each practice by their MSMC on a 5-point Likert Scale (1 - Not adopted to 5 - Very highly adopted). The respondents for the questionnaire were senior level managers who are well aware of SCM adoption and implementation. A reliability test of initial data from 28 companies, whose results are provided in Table 1, indicate that the lower bound of true reliability is 0.979 . Hence, it was decided to continue further with the additional data collection and further analysis.

Table 1 Reliability Statistics

\begin{tabular}{|c|c|c|}
\hline Cronbach's Alpha & $\begin{array}{c}\text { Cronbach's Alpha Based } \\
\text { on Standardized Items }\end{array}$ & N of Items \\
\hline .979 & .980 & 28 \\
\hline
\end{tabular}

\section{RESULTS AND DISCUSSION}

The responses related to degree of SC awareness were collected through three questions, i.e., i) Organization's level of awareness about SCM, ii) Investment by the top management in SCM related aspects and iii) Perception on role of SCM in reducing costs on a 5-point Likert Scale (1Very Low to 5-Very High). An Optimal Scaling Technique (OST) (Jacqueline, 1998), was employed using Categorical Principal Components Analysis (CATPCA) to discretize the scores based on the responses for each individual variable. Overall Component score (Object Score) integrating the responses of all questions related to $\mathrm{SC}$ awareness variable was computed and was assigned to a variable titled 'Awareness Score'. This awareness score is statistically tested differentiated by each sector, size, capital investment, product variety and length of existence of MSMC.

The frequency table, quantification related to these three questions, model summary and component loadings are presented in Table 2, Table 3 and Table 4. The quantification values in these tables are the normalized values of responses, obtained through CATPCA technique (Jon and Richard, 2014). Cronbach's Alpha of 0.904 in Table 3 suggests the appropriateness of the technique to transform the variables into a single component. Table 3 also indicates high component loading for each variable and the importance associated with each of the variable. It is 
Yanamandra: Investigating the Influence of Organizational Factors on Supply Chain Awareness Operations and Supply Chain Management 14 (2) pp. 189 - 202 (C) 2021

observed that one single component captures approximately $84 \%$ of the variability of the individual variables. The object score based on the component loading computed for each case is used for comparison purposes.

Table 2 Results of Organization's Degree of SC Awareness

\begin{tabular}{|c|c|c|}
\hline & Frequency & Quantification \\
\hline Very Low & 1 & -4.462 \\
\hline Low & 34 & -1.505 \\
\hline Medium & 46 & 0.206 \\
\hline High & 53 & 0.761 \\
\hline Very High & 4 & 1.454 \\
\hline Total & 138 & \\
\hline
\end{tabular}

2. Investment by top Management in SCM related aspects

\begin{tabular}{|l|c|c|}
\hline Very Low & 3 & -3.363 \\
\hline Low & 52 & -1.000 \\
\hline Medium & 56 & 0.580 \\
\hline High & 26 & 1.061 \\
\hline Very High Total & 138 & 1.987 \\
\hline \multicolumn{2}{|c|}{ 3. Role of SCM in Cost Reduction } \\
\hline Very Low & 5 & -2.915 \\
\hline Low & 59 & -0.817 \\
\hline Medium & 52 & 0.737 \\
\hline High & 20 & 1.049 \\
\hline Very High & 2 & 1.716 \\
\hline Total & 138 & \\
\hline
\end{tabular}

Table 3 Model Summary of Organization's Degree of Awareness

\begin{tabular}{|c|c|c|c|}
\hline \multirow{2}{*}{ Component } & \multirow{2}{*}{$\begin{array}{c}\text { Cronbach's } \\
\text { Alpha }\end{array}$} & \multicolumn{2}{|c|}{ Variance Accounted For } \\
\cline { 3 - 4 } & .904 & 2.518 & 83.942 \\
\hline 1 & .904 & 2.518 & 83.942 \\
\hline Total & & \\
\hline \multicolumn{2}{|l|}{ Component Loading } & Component \\
\cline { 3 - 4 } & 1 \\
\hline $\begin{array}{l}\text { Organization's Awareness about SCM by the top } \\
\text { management }\end{array}$ & .868 \\
\hline $\begin{array}{l}\text { Investment by Top Management in SCM related } \\
\text { aspects }\end{array}$ & .950 \\
\hline \begin{tabular}{l} 
Role of SCM in reducing costs \\
\hline
\end{tabular}
\end{tabular}

A one-way ANOVA with Post Hoc tests for pair wise differences in the Awareness Score was performed and these results are presented in Table 4. It indicates that the Average Awareness Score is slightly positive for electrical/electronic and pharmaceutical sectors, while it is marginally negative for engineering and chemical Sectors. The significance value $>0.05$ reveals that there is not much deviation in the variance too. The significance value ( $p$-value $>0.05$ ) of one-way ANOVA test does not indicate significant difference in the degree of SC awareness score levels across different sectors of MSMCs. The robust tests for equality of means also carry a significance value of $>0.05$, indicating no statistically significant differences between the means across the sectors. Therefore, it is interpreted that the degree of SC awareness across select Industry sectors of MSMCs is uniform validating the first hypothesis $(\mathrm{H} 1)$. These results significantly differ with the results of Kwan, (1999) and Jharkharia and Shankar, (2006), who identified a significant difference in degree of SC awareness between electronic and chemical industries of MSMCs. This deviation may be due to the consideration of four sectors of MSMCs in the present study rather than just two sectors.

Table 4 Mean and Standard Deviation values for Sector-Wise Degree of Awareness

\begin{tabular}{|l|c|c|c|}
\hline \multicolumn{1}{|c|}{ Industry Sector } & $\mathrm{N}$ & Mean & Std. Deviation \\
\hline Engineering & 59 & -.0726 & 1.00247 \\
\hline Chemical & 27 & -.1536 & 1.06599 \\
\hline Electrical/Electronics & 23 & .0168 & 1.02612 \\
\hline Pharmaceutical & 29 & .2774 & .92231 \\
\hline Total & 138 & .0000 & 1.00364 \\
\hline
\end{tabular}

Test of Homogeneity of Variance (HoV)

\begin{tabular}{|c|c|c|c|}
\hline Levene Statistic & $\mathrm{df1}$ & $\mathrm{df} 2$ & Sig. \\
\hline 1.115 & 3 & 134 & $\mathbf{3 4 5}$ \\
\hline
\end{tabular}

Results of One-Way ANOVA test for Sector-wise degree of awareness about SCM

\begin{tabular}{|c|c|c|c|c|c|}
\hline & $\begin{array}{c}\text { Sum of } \\
\text { Squares }\end{array}$ & Df & $\begin{array}{c}\text { Mean } \\
\text { Square }\end{array}$ & $\mathrm{F}$ & Sig. \\
\hline $\begin{array}{c}\text { Between } \\
\text { Groups }\end{array}$ & 3.185 & 3 & 1.062 & 1.055 & .370 \\
\hline Within & 134.815 & 134 & 1.006 & & \\
\hline Total & 138.000 & 137 & & & \\
\hline
\end{tabular}

Robust Tests for Equality of Means

\begin{tabular}{|c|c|c|c|c|}
\hline Test & Statistic $^{a}$ & df1 & df2 & Sig. \\
\hline Welch & 1.132 & 3 & 59.079 & .344 \\
\hline Brown-Forsythe & 1.048 & 3 & 103.797 & .375 \\
\hline \multicolumn{5}{|c|}{ a. Asymptotically F distributed. } \\
\hline
\end{tabular}

Similarly, a one-way ANOVA with Post Hoc tests for pair wise differences in the Awareness Score was done to study the influence of size (number of employees), capital investment ( 5 to 10 crore in Indian rupees), and product variety (a minimum of 3 to maximum of 12 products), whereas, a bivariate correlation is conducted for length of existence. These results are presented in Table 5, Table 6, Table 7. The results of Table 5 indicate that MSMCs with employees more than 200 have more degree of SC awareness in comparison with other MSMCs whose number of employees is less than 200. Therefore, it is interpreted that the degree of SC awareness is more in companies which have more number of employees (size). This interpretation corroborates with the results of Juliana et al., (2013) and Hariharan et al., (2019). Also, the results from Table 6 indicate that the degree of SC awareness of companies with 9 to10 crore (Indian Rupees) capital investment is much higher compared to companies with lower categories of 
capital investments. Therefore, it is interpreted that the degree of SC awareness varies with respect to the capital investment in MSMCs. It appears that

higher the capital investment, the higher is the company's degree of SC awareness. These results corroborate with the results of Afande et al., (2015). Analysis of results in Table 7 reveals that the degree of SC awareness Operations and Supply Chain Management 14 (2) pp. 189 - 202@ 2021

is significantly higher in MSMCs which manufacture more product varieties (greater than nine) compared to those manufacturing fewer varieties (less than nine) and thus the second $(\mathrm{H} 2)$, third $(\mathrm{H} 3)$ and fourth $(\mathrm{H} 4)$ hypotheses are validated.

Table 5 Results related to Number of Employees (Size of the organization) and Degree of Awareness about SCM (Mean, SD, Test of Homogeneity of Variance, One way ANOVA, Test of Equality of Means and Post-hoc Tests of pairwise differences)

\begin{tabular}{|c|c|c|c|c|c|}
\hline No. of Employees & $\mathbf{N}$ & Mean & Std. Deviation & Std. Error & \\
\hline $51-100$ & 5 & -.0496 & .93732 & .41918 & \\
\hline $101-150$ & 17 & -.8200 & 1.30302 & .31603 & \\
\hline $151-200$ & 45 & -.2095 & .89462 & .13336 & \\
\hline$>200$ & 70 & .3294 & .85784 & .10253 & \\
\hline Total & 137 & -.0041 & 1.00617 & .08596 & \\
\hline \multicolumn{6}{|c|}{ Test of Homogeneity of Variance (HoV) } \\
\hline Levene Statistic & df1 & df2 & Sig. & & \\
\hline 1.698 & 3 & 133 & 171 & & \\
\hline \multicolumn{6}{|c|}{ Results of One-Way ANOVA test for Size of Company (Number of Employees) and it's Degree of Awareness about SCM } \\
\hline & Sum of Squares & Df & Mean Square & F & Sig. \\
\hline Between Groups & 21.010 & 3 & 7.003 & 7.983 & .000 \\
\hline Within Groups & 116.672 & 133 & .877 & & \\
\hline Total & 137.682 & 136 & & & \\
\hline \multicolumn{6}{|l|}{ Robust Test for Equality of Means } \\
\hline & Statistic $^{a}$ & df1 & df2 & Sig. & \\
\hline Welch & 5.801 & 3 & 16.601 & .007 & \\
\hline Brown-Forsythe & 6.503 & 3 & 32.042 & .001 & \\
\hline \multicolumn{6}{|c|}{ a. Asymptotically F distributed } \\
\hline \multicolumn{6}{|c|}{ Post-Hoc Tests for pairwise differences } \\
\hline (I) Number of Employees & (J) Number of Employees & $\begin{array}{l}\text { Mean Difference } \\
(I-J)\end{array}$ & Std. Error & Sig. & \\
\hline \multirow{3}{*}{$51-100$} & $101-150$ & .77040 & .47650 & .373 & \\
\hline & $151-200$ & .15996 & .44152 & .984 & \\
\hline & $>200$ & -.37895 & .43357 & .818 & \\
\hline \multirow{3}{*}{$101-150$} & $51-100$ & -.77040 & .47650 & .373 & \\
\hline & $151-200$ & -.61044 & .26664 & .106 & \\
\hline & $>200$ & $-1.14935^{\star}$ & .25325 & .000 & \\
\hline \multirow{3}{*}{$151-200$} & $51-100$ & -.15996 & .44152 & .984 & \\
\hline & $101-150$ & .61044 & .26664 & .106 & \\
\hline & $>200$ & $-.53891^{\star}$ & .17896 & .016 & \\
\hline \multirow{3}{*}{$>200$} & $51-100$ & .37895 & .43357 & .818 & \\
\hline & $101-150$ & $1.14935^{\star}$ & .25325 & .000 & \\
\hline & $151-200$ & $.53891^{*}$ & .17896 & .016 & \\
\hline
\end{tabular}


Yanamandra: Investigating the Influence of Organizational Factors on Supply Chain Awareness

Operations and Supply Chain Management 14 (2) pp. 189 - 202 (C) 2021

Table 6 Results related to Capital Investment and Degree of Awareness about SCM (Mean, SD, Test of Homogeneity of Variance, Oneway ANOVA, Test of Equality of Means and Post-hoc Tests of pairwise differences)

\begin{tabular}{|c|c|c|c|c|c|}
\hline $\begin{array}{l}\text { Capital Investment (in Indian } \\
\text { Rupees in Crores) }\end{array}$ & $\mathbf{N}$ & Mean & Std. Deviation & & \\
\hline $5-6$ & 31 & -.6007 & 1.19356 & & \\
\hline $6-7$ & 12 & .0404 & .70067 & & \\
\hline $7-8$ & 14 & -.3412 & 1.11708 & & \\
\hline $8-9$ & 23 & -.2677 & .81660 & & \\
\hline $9-10$ & 58 & .5012 & .72443 & & \\
\hline Total & 138 & .0000 & 1.00364 & & \\
\hline \multicolumn{4}{|l|}{ Test of Homogeneity of Variance (HoV) } & & \\
\hline Levene Statistic & df1 & df2 & Sig. & & \\
\hline 4.244 & 4 & 133 & .003 & & \\
\hline \multicolumn{6}{|l|}{ Results of One-Way ANOVA test } \\
\hline & Sum of Squares & Df & Mean Square & $\mathrm{F}$ & Sig. \\
\hline Between Groups & 29.055 & 4 & 7.264 & 8.868 & .000 \\
\hline Within Groups & 108.945 & 133 & .819 & & \\
\hline Total & 138.000 & 137 & & & \\
\hline \multicolumn{6}{|l|}{ Robust Tests for Equality of Means } \\
\hline & Statistic $^{a}$ & df1 & df2 & Sig. & \\
\hline Welch & 8.312 & 4 & 39.927 & .000 & \\
\hline Brown-Forsythe & 8.221 & 4 & 72.906 & .000 & \\
\hline \multicolumn{6}{|c|}{ a. Asymptotically $\mathrm{F}$ distributed. } \\
\hline \multicolumn{6}{|l|}{ Post Hoc Tests } \\
\hline $\begin{array}{l}\text { (I) Capital Investment (Indian Rupees } \\
\text { in Crores) }\end{array}$ & $\begin{array}{l}\text { (J) Capital Investment (In } \\
\text { Indian rupees in Crores) }\end{array}$ & $\begin{array}{l}\text { Mean Difference } \\
(I-J)\end{array}$ & Sig. & & \\
\hline \multirow{4}{*}{ 5-6 Crores } & $6-7$ & -64111 & .233 & & \\
\hline & $7-8$ & -.25946 & .900 & & \\
\hline & $8-9$ & -.33297 & .669 & & \\
\hline & $9-10$ & $-1.10191^{*}$ & .000 & & \\
\hline \multirow{4}{*}{ 6-7 Crores } & $5-6$ & .64111 & .233 & & \\
\hline & $7-8$ & .38165 & .821 & & \\
\hline & $8-9$ & .30814 & .874 & & \\
\hline & $9-10$ & -.46080 & .497 & & \\
\hline \multirow{4}{*}{ 7-8 Crores } & $5-6$ & .25946 & .900 & & \\
\hline & $6-7$ & -.38165 & .821 & & \\
\hline & $8-9$ & -.07351 & .999 & & \\
\hline & $9-10$ & $-.84245^{*}$ & .018 & & \\
\hline \multirow{4}{*}{ 8-9 Crores } & $5-6$ & .33297 & .669 & & \\
\hline & $6-7$ & -30814 & .874 & & \\
\hline & $7-8$ & .07351 & .999 & & \\
\hline & $9-10$ & $-.76894^{*}$ & .007 & & \\
\hline \multirow{4}{*}{ 9-10 Crores } & $5-6$ & $1.10191^{*}$ & .000 & & \\
\hline & $6-7$ & .46080 & .497 & & \\
\hline & $7-8$ & $.84245^{\star}$ & .018 & & \\
\hline & $8-9$ & $.76894^{*}$ & .007 & & \\
\hline
\end{tabular}


Table 7 Results related to Product Variety and Degree of Awareness about SCM (Mean, SD, Test of Homogeneity of Variance, One way ANOVA, Robust Test of Equality of Means)

\begin{tabular}{|c|c|c|c|c|c|}
\hline No. of Product Variety & $\mathrm{N}$ & Mean & Std. Deviation & & \\
\hline 3-6 & 23 & -.1569 & .95188 & & \\
\hline $6-9$ & 55 & -.2649 & 1.03321 & & \\
\hline $9-12$ & 31 & .0153 & .97838 & & \\
\hline$>12$ & 28 & .5988 & .77837 & & \\
\hline Total & 137 & -.0068 & 1.00411 & & \\
\hline \multicolumn{6}{|c|}{ Test of Homogeneity of Variance (HoV) } \\
\hline Levene Statistic & df1 & df2 & Sig. & & \\
\hline 2.184 & 3 & 133 & .093 & & \\
\hline \multicolumn{6}{|c|}{ Results of One-Way ANOVA test between Organization's SCM Awareness and No. of Product Varieties } \\
\hline & Sum of Squares & df & Mean Square & $\mathrm{F}$ & Sig. \\
\hline Between Groups & 14.464 & 3 & 4.821 & 5.228 & .002 \\
\hline Within Groups & 122.656 & 133 & .922 & & \\
\hline Total & 137.120 & 136 & & & \\
\hline \multicolumn{6}{|l|}{ Robust Tests for Equality of Means } \\
\hline & Statistica & df1 & df2 & Sig. & \\
\hline Welch & 6.562 & 3 & 63.055 & .001 & \\
\hline Brown-Forsythe & 5.530 & 3 & 113.473 & .001 & \\
\hline
\end{tabular}

To interpret the results related to length of existence (experience), a Bivariate Correlation test between length of existence of MSMC and Average Awareness Score was conducted. Length of existence of MSMC was calculated as the number of years of existence of MSMC till end of June, 2019 from its year of establishment. The results presented in Table 8 indicate that there is a significant relationship between length of existence and degree of SC awareness, though it is little weak (correlation is 0.175 with a significance of 0.04). Therefore, it is interpreted that higher the length of existence, the higher is the degree of awareness of SCM which validates the fourth hypothesis (H5). These results corroborate with the results of Juliana et al. (2013), who also found that there is a significant difference between experience of organization and degree of SC awareness.

The influence of degree of SC awareness on the degree of adoption of SC practices is interpreted by integrating the responses related to the degree of adoption of nineteen SC practices to arrive at a new variable named as "NumAspects". A Bivariate Correlation test (Table 9) between the Average Awareness Score and this new variable NumAspects indicates that there is a significant positive correlation relationship between degree of SC awareness and degree of adoption of SC practices. This validates the sixth hypothesis and these findings corroborate with the findings of (Juliana et al., 2013; Gorane and Ravikant, 2014; Youqin et al., 2013; Mishra, 2019).
Table 8 Results of Bivariate Correlation between Awareness Score and Length of Existence (Experience) of the Company

\begin{tabular}{|c|c|c|c|}
\hline & & Awareness & $\begin{array}{l}\text { Length of } \\
\text { Existence }\end{array}$ \\
\hline \multirow{3}{*}{ Awareness } & Pearson Correlation & 1 & $.675^{\star}$ \\
\hline & Sig. (2-tailed) & & .040 \\
\hline & $\mathrm{N}$ & 138 & 138 \\
\hline \multirow{3}{*}{$\begin{array}{l}\text { Length of } \\
\text { Existence }\end{array}$} & Pearson Correlation & $.675^{*}$ & 1 \\
\hline & Sig. (2-tailed) & .040 & \\
\hline & $\mathrm{N}$ & 138 & 138 \\
\hline
\end{tabular}

\section{CONCLUSIONS AND SCOPE FOR FUTURE RESEARCH}

The analysis and interpretation of this research revealed some interesting findings related to the influence of organizational factors on degree of SC awareness in MSMCs. The degree of SC awareness is uniform across the four sectors considered for this study. Organizational factors of MSMCs such as size, length of existence, capital investment and variety of products manufactured influence the degree of SCA positively. The degree of SCA is significantly higher in those companies which have more 
than two hundred number of employees. The degree of SC awareness is higher in companies whose capital investment is greater than 9 crores and less than 10 crores (Indian Rupees) and less in MSMCs whose capital investment is less than 9 crores. MSMCs which have more years of existence are found to be having higher levels of degree of SC awareness. It can also be concluded that higher the product variety, higher is the degree of SC awareness in MSMCs in the select sectors. Thus, companies which are manufacturing more variety (greater than 12 in the present study) of products are found to be having more awareness about SCM. The degree of SC awareness in the MSMCs which manufacture less number of product variety is found to be less. Nineteen SC practices were identified to be the most popular ones among the MSMCs based on the systematic literature. Adoption of these practices by the MSMCs is found to get influenced due to degree of SC awareness. Higher the degree of SC awareness, higher is the adoption of $\mathrm{SC}$ practices. These conclusions are corroborated with the conclusions of various authors as mentioned in the above section.

Table 9 Pearson Correlation between Average Awareness Score and NumAspects

\begin{tabular}{|l|c|}
\hline & NumAspects \\
\hline Pearson Correlation (Awareness Score) & $.676^{* *}$ \\
\hline Sig. (2-tailed) & .000 \\
\hline $\mathrm{N}$ & 138 \\
\hline
\end{tabular}

The present research is limited to MSMCs from four popular industry sectors. An empirical study by considering more number of industry sectors with the inclusion of many other SC practices will be the topic for future research. Also, the geographical scope of the study can be expanded by including more number of regions in future.

\section{IMPLICATIONS AND RECOMMENDATIONS}

Supply chain awareness (SCA) is an important prerequisite for adoption of SC practices and for successful implementation of SCM (Youqin et al., 2013; Juliana et al., 2013; Thoo et al., 2017). The findings of this research develop an awareness among supply chain managers of MSMCs. It also provides a menu of nineteen highly popular SC practices in MSMCs which can be adopted for achieving positive outcomes. MSMCs can gain competitive advantage in the globalized business environment by implementing these SC practices. Outcomes of this paper will also enable the organizations to identify and direct their focus on the areas that require improvement. Also, the MSMCs will become more aware of the SCPs that will help to increase their performance and competitiveness. With best SCPs, MSMCs will be able to improve their business performance and expand their assets, providing work opportunities and indirectly boosting the growth and contribute to economic development of country. Also, the present research fills the gaps in the existing body of knowledge related to SCM in MSMCs and it will enable researchers to dwell more into SC practices.

Top management awareness and commitment towards SCM initiatives and practices is essential for successful implementation of SCM. It is recommended that the managers of MSMCs commence the implementation of SC practices by considering the influence of various organizational factors. Also, there is an urgent need to develop supply chain awareness among the owners and managers of these enterprises.

\section{REFERENCES}

Afande, Francis Ofunya., Bonface Matayo Ratemo and Fredrick Nyagari Nyaribo. (2015). Adoption of Supply Chain Management Practices: Review of Determining Factors. Innovative Systems Design and Engineering 6(5), pp. 72-77

Ahlstedt, Dan and Hameri, Ari-Pekka. (2004). Review of Supply Chain Management Research: Practical Business Value and International Aspect. Supply Chain Forum: an International Journal 5(10), pp. 38-48. DOI: 10.1080/16258312.2004.11517125.

Alhourani, F. and Saxena. U. (2014). Supply Chain Management practices in US Industrial SMEs. International Journal of Business Research 14(2), pp.7-18. https://doi.org/ 10.18374/IJBR-14-2.1

Al-Shboul, Moh'd Anwer Radwan., Kevin D. Barber, Jose Arturo Garza-Reyes, Vikas Kumar, and Reza Abdi M. (2017). The effect of supply chain management practices on supply chain and manufacturing firms' performance. Journal of Manufacturing Technology Management 28(5), pp. 577-609.

Arend R.J. and Wisner. J.D. (2005). Small business and Supply Chain Management: Is there a fit? Journal of Business Venturing 20(3), pp. 403-36

Atnafu and Balda. (2018). The impact of inventory management practice on firms' competitiveness and organizational performance: Empirical evidence from micro and small enterprises in Ethiopia. Cogent Business \& Management 5, https://doi.org/10.1080/23311975.2018.1503219.

Atul B. Borade and Satish V. Bansod. (2010). Study of vendor-managed inventory practices in Indian industries. Journal of Manufacturing and Technology Management 21(8), pp. 1013-1038.

Bak, O., Jordan, C. and Midgley, J. (2019). The adoption of soft skills in supply chain and understanding their current role in supply chain management skills agenda: A UK perspective. Benchmarking: An International Journal 26(3), pp. 10631079. https://doi.org/10.1108/BIJ-05-2018-0118

Bala., Subrahmanya M. H. (2007). Development strategic for Indian SMEs: promoting linkages with global transnational corporations. Management Research News 30(10), pp. 762-774.

Baruffaldi, G., Accorsi, R. and Manzini, R. (2019). Warehouse management system customization and information availability in $3 \mathrm{pl}$ companies: A decisionsupport tool. Industrial Management \& Data Systems 119(2), pp. 251-273. https://doi.org/10.1108/IMDS01-2018-0033

Burgess, K., Singh, P.J. and Koroglu. R. (2006). Supply chain management: a structured literature review and implications for future research. International Journal of Operations \& Production Management 26(7), pp. 703-29. 
Wang. Charles X (2002). A general framework of supply chain contract model. Supply Chain Management: An International Journal 7(5), pp. 302-310.

Chakraborty, S. and Gonzalez A. Jorge (2018). An integrated lean supply chain framework for U.S. hospitals. Operations and Supply Chain Management 11(2), pp 98-109

Chen H., Themistocleous M. and Chiu K. (2004). Approaches to Supply Chain Integration Followed by SMEs: An Exploratory Case Study. New York: Proceedings of The Tenth Americas Conference on Information Systems.

Chopra, S. and Meindl. P. (2013). Supply Chain Management: Strategy, Planning, and Operations. $5^{\text {th }}$ Edition, Prentice Hall.

Cook, L.S., Heiser, D.R. and Sengupta. K. (2011). The moderating effect of supply chain role on the relationship between supply chain practices and performance an empirical analysis. International Journal of Physical Distribution and Logistics Management 41(2), pp. 104-134.

Council of Supply Chain Management Professionals (CSCMP). (2019). CSCMP Supply Chain Management Definitions and Glossary, https://cscmp.org/CSCMP/Educate/SCM_Definitions and_Glossary_of_Terms.aspx (Accessed on 8th Dec, 2019)

Cousins, P., Lawson, B. and Squire, B. (2008). Performance measurement in strategic buyer supplier relationships: the mediating role of socialization mechanisms. International Journal of Operations and Production Management 28(3), pp. 238-258.

Coyle, J.J., Langley, C.J., Novack, R.A. \& Gibson, B.J., (2017). Supply Chain Management: A logistics perspective 10th edn., Cengage Learning, Boston, MA.

Defee, Cliff. (2006). Creating Competitive Advantage Using Non-Equity Strategic Alliances: A Small Company Perspective. Supply Chain Forum: an International Journal. 7(2), pp. 44-57. 10.1080/16258312.2006.11517168.

Didonet, Simone and Diaz Villavicencio, Guillermo. (2012). Supply Chain Management Practices as a Support to Innovation in SMEs. Journal of Technology Management \& Innovation 7(3), pp. 91-109. 10.4067/S0718-27242012000300009.

Dyer, J. and Singh, J. (1998). The relational view: cooperative strategy and sources of inter-organizational competitive advantage. Academy of Management Review 23(4), pp. 660-79.

Ellram, L.M. and Cooper, M.C. (1990). Supply chain management, partnerships, and the shipper: third party relationship. The International Journal of Logistics Management 1(2), pp. 1-10.

Ellram, L.M. (1995). Partnering pitfalls and success factors. International Journal of Purchasing and Materials Management 31(2), pp. 36-44.

Forman, H. and Lippert, S.K. (2005). Toward the development of an integrated model of technology internalization within the supply chain context. The International Journal of Logistics Management, 16(1), pp. 4-27.
Frohlich, M. and Westbrook, R. (2002). Demand chain management in manufacturing and services: web-based integration, drivers and performance. Journal of Operations Management 20, pp. 729-45.

Ghosh, M. (2012). Lean manufacturing performance in Indian manufacturing plants. Journal of Manufacturing Technology Management 24(1) pp. 113-122.

Gorane S. J., and Ravikant. (2014). Supply chain practices: An implementation status in Indian manufacturing organizations. Benchmarking: An International Journal 23(5), pp. 1076-1110.

Grant, R.M. (1991). The resource-based theory of competitive advantage: implications for strategy formulation. California Management Review 33(33), pp. 114-35.

Gunasekaran, A., Okko, P., Martikainen, T. and Yli-Olli, P. (1996). Improving productivity and quality in small and medium enterprises: cases and analysis. International Small Business Journal 15(1), pp. 59-72.

Halldorsson, Arni., Herbert Kotzab, Juliana H. Mikkola and Tage Skjøtt-Larsen (2007). Complementary theories to supply chain Management. Supply Chain Management: An International Journal 12(4), pp. 284-296

Hariharan, G., Suresh, P., Sagunthala, C. (2019). Critical Success Factors for the Implementation of Supply Chain Management in SMEs, International Journal of Recent Technology and Engineering (IJRTE) 7(5S3), pp. 540-544. ISSN: 2277-3878.

Harrison, A. and New, C. (2002). The Role of Coherent Supply Chain Strategy and Performance Management in Achieving Competitive Advantage: An International Survey. Journal of the Operational Research Society 53(3), pp. 263-71.

Holweg, M., Disney, S., Holmstrom, J. and Smaros, J. (2005). Supply chain collaboration: making sense of the strategy continuum. European Management Journal 23(2), pp. 170-81.

Higginson., James K. and Ashraful Alam, (1997). Supply Chain Management Techniques in Medium-to-Small Manufacturing Firms. The International Journal of Logistics Management 8(2). pp. 19-32.

Huddiniah \& ER: Product Variety, Supply Chain Complexity and the Needs for Information Technology: A Framework Based on Literature Review 246 Operations and Supply Chain Management 12(4) pp. 245 - 255 (C) 2019

Jacqueline. Meulman, (1998). Optimal Scaling Methods for Multivariate Categorical Data Analysis, A white paper on SPSS, 1-12. http://hbanaszak.mjr.uw.edu.pl/TempTxt/Meulman_2 00X_OptimalScalingMethodsForMultivariateCategori calData_SPSSWhitePaper.pdf)

Jharkharia, Sanjay and Shankar, Ravi. (2006). Supply chain management: some sectoral dissimilarities in the Indian manufacturing industry, Supply Chain Management: An International Journal 11(4), pp. 345-52.

Juliana, Micheline Naude. (2013). Supply chain challenges in the South African automotive sector: Do location, size and age matter. South African Journal of Economic and Management Sciences 16(4), pp. 407-417. 
Yanamandra: Investigating the Influence of Organizational Factors on Supply Chain Awareness

Jon Starkweathe and Richard Herrington. (2014). Categorical Principal Components with Optimal Scaling. SPSS-SC, Module-9, University of NT (http://www.unt.edu/rss/class/Jon/SPSS_SC/Module9/ M9 CATPCA/SPSS M9 CATPCA.htm)

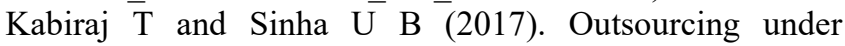
Incomplete Information, Indian Growth and Development Review 10(1), pp. 3-15.

Khan Habibullah and Wisner JD (2019). Supply Chain Integration, Learning, and Agility: Effects on Performance. Operations and Supply Chain Management 12(1), pp. 14-23. ISSN 1979-3561 | EISSN 2759-9363

Koh, S.C.L., Sevkli, E., Zaim, S., Demirbag, M. and Tatoglu, E. (2007). The impact of supply chain management practices on performance of SMEs. Industrial Management and Data Systems 107(1), pp. 103-124.

Kot, S., Goldbach, I. R., and Ślusarczyk, B. (2018). Supply chain management in SMEs - Polish and Romanian approach. Economics and Sociology 11(4), pp. 142156. doi:10.14254/2071-789X.2018/11-4/9

Kwak, Dong-Wook., Young-Joon Seo, and Robert Mason. (2018). Investigating the relationship between supply chain innovation, risk management capabilities and competitive advantage in global supply chains. International Journal of Operations \& Production Management 38(1), pp. 2-21.

Kwan, A. T. W. (1999). The use of information technology to enhance supply chain management in the electronics and chemical industries. Production and Inventory Management Journal 40(3), pp. 7-15.

Lambert, D.M. and Cooper, M.C. (2000). Issues in supply chain management. Industrial Marketing Management 29(1), pp. 65-83.

Larry C. Giunipero, and Richard R. Brand. (1996). Purchasing Role in Supply Chain Management. The International Journal of Logistics Management 7(1), pp. $29-38$.

Lepoutre, J. and Heene, A. (2006). Investigating the impact of firm size on small business social responsibility: a critical review. Journal of Business Ethics 67, pp. 257273.

Lewis, M.A. (2000). Lean production and sustainable competitive advantage. International Journal of Operations and Production Management 20(8), pp. 959-78.

Li, S., Ragu-Nathan, B., Ragu-Nathan, T.S. and Subba Rao, S. (2006). The impact of supply chain management practices on competitive advantage and organizational performance. Omega 34(2), pp. 107-124.

Li, X., Wu, Q., Holsapple, C.W. and Goldsby, T. (2017). An empirical examination of firm financial performance along dimensions of supply chain resilience. Management Research Review 40(3), 254-269

Maguire, S. and Magrys, A. (2001). The potential use of IT to gain competitive advantage for small and mediumsized enterprises. Proceedings of the 9th Annual High Technology Small Firms Conference, Manchester Business School, Manchester.

Martin Christopher and Matthias Holweg. (2011). Supply Chain 2.0: managing supply chains in the era of turbulence. International Journal of Physical
Distribution and Logistics Management 41(1), pp. 6382.

Mathu, K.M., (2019). The information technology role in supplier-customer information-sharing in the supply chain management of South African small and medium-sized enterprises. South African Journal of Economic and Management Sciences 22(1), a2256. https://doi.org/10.4102/ sajems.v22i1.2256

Metilda, R.M. and Vivekanandan, K. (2011). Impact of supply chain management practices on the competitive advantage of Indian retail supermarkets. International Journal of Logistics Systems and Management 9(2), pp. $170-185$

Mentzer John (2001). Defining Supply Chain Management. Journal of Business Logistics 22(2), 5

Mishra Rohita Kumar (2019). Evaluation of Supply Chain Activities in Indian SMEs: A Fuzzy AHP Approach. IUP Journal of Supply Chain Management 16(3), pp. 36-57.

Na., Sakolnakorn (2011). The Good Aspects of Managing an Organization with an Outsourcing and Subcontracting Strategy. International Journal of Management and Information Systems 15(3), ABI/INFORM Complete, 11.

Niranjan, K. (2012). A study of Supply Chain Management in MSMEs and Performance Management, Thesis submitted to Berhampur University, Orissa, India

Pagell, M. and Krause, D.R. (2004). Re-exploring the relationship between flexibility and the external environment. Journal of Operations Management 21(6), pp. 629-649.

Paik Seung-Kuk (2011) Supply Management in Small and Medium-Sized Enterprises: Role of SME Size. Supply Chain Forum: An International Journal 12(3), pp. 1021, DOI: $10.1080 / 16258312.2011 .11517269$

Pandza, K., Polajnar, A., Buchmeister, B. and Thorpe, R. (2003). Evolutionary perspectives on the capability accumulation process. International Journal of Operations \& Production Management 23(7/8), pp. 822-49.

Paul Hong and Jungsik Jeong. (2006). Supply chain management practices of SMEs: from a business growth perspective. Journal of Enterprise Information Management 19(3), pp. 292 - 302.

Porter G. Mary (2019). Supply Chain Integration: Does Organizational Culture Matter? Operations and Supply Chain Management 12(1), pp. 49-59. ISSN 1979-3561 | EISSN 2759-9363

Prahalad, C. and Hamel, G. (1990). The core competence of the corporation. Harvard Business Review 68(3), pp. 79-91.

Premkumar, G. and Ramamurthy, K. (1995). The role of inter-organizational and organizational factors on the decision mode for adoption of inter-organizational systems. Decision Sciences 26(3), pp. 303-36.

Quayle, (2003). A study of supply chain management practice in UK industrial SMEs. Supply Chain Management: An International Journal 8(1), pp. 79-86.

Rajesh K. Singh, Suresh K. Garg, and Deshmukh, S. G. (2008). Competency and Performance analysis of Indian SMEs and large organizations: An exploratory 
study. Competitiveness Review: An International Business Journal 18(4), pp. 308-321.

Ramakrishna Y., (2016), Supply Chain Management: Large vs. Small and Medium Enterprises (SMEs), In Ashish Dwivedi. Innovative Solutions for Implementing Global Supply Chains in Emerging Markets, IGI Global, pp. 141-151.

Reitsma, E., Hilletofth, P., Mukhtar, U. (2018). Enterprise Resource Planning System Implementation: a User Perspective. Operations and Supply Chain Management 11(3), pp 110-117.

Rouhollah Zahedirad and Shivraj, B. (2011). Supply Chain: Barriers and Benefits in Indian SMEs. SCMS Journal of Indian Management 8(4), pp. 11-30.

Rungtusanatham, M., Salvador, F., Forza, C. and Choi, T.Y. (2003). Supply-chain linkages and operational performance: a resource-based-view perspective. International Journal of Operations \& Production Management 23(9), pp. 1084-99.

Sahay B. S. and Ramneesh Mohan, (2003). Supply Chain Management practices in Indian Industry. International Journal of Physical Distribution \& Logistics Management 33(7), pp. 582-606.

Sahay, B.S., Gupta, N.D. and Mohan, R. (2006). Managing supply chains for competitiveness: The Indian scenario. Supply Chain Management: An International Journal 11(1), pp. 15-24.

Salam, A., Panahifar, F. \& Byrne, P.J., (2016). Retail supply chain service levels: The role of inventory storage. Journal of Enterprise Information Management 29(6), pp. 887-902. https://doi.org/10.1108/JEIM-01-20150008

Simchi-Levi, D., Kaminsky, P. and Simchi-Levi, E. (2009). Designing and Managing the Supply Chain: Concepts, Strategies, and Case Studies. TATA McGraw-Hill, Third Edition.

Singhry, H.B. and Abd Rahman, A. (2019). Enhancing supply chain performance through collaborative planning, forecasting, and replenishment. Business Process Management Journal 25(4), pp. 625646. https://doi.org/10.1108/BPMJ-03-2017-0052

Stock, J. R. and Boyer, S. L. (2009). Developing a Consensus Definition of a Supply Chain Management: A Qualitative Study. International Journal of Physical Distribution \& Logistics Management 39(8), pp. 690711.

Stonkute, E. (2015). A Literature Review on the Linkage between Supply Chain Challenges and Key Success Factors for Small and Medium Size Enterprises. ORGANIZACIJU VADYBA: SISTEMINIAI TYRIMAI, pp.

121-138. http://dx.doi.org/10.7220/MOSR.2335.8750.2015.74.8

Sujatha, R. (2011). Role of intelligent agents in facilitating information flow in supply chain management. International Journal of Logistics Systems and Management 9(2), pp. 229-237.

Tan, K.C., Lyman, S.B. and Wisner, J.D. (2002). Supply chain management: a strategic perspective. International Journal of Operations and Production Management 22(6), pp. 614-31.
Teo, T., Chan, C. and Paker, C. (2004). Factors affecting ecommerce adoption by SMEs: a meta-analysis, Proceedings of Australasian Conference on Information Systems, Hobart, Australia, 1-3 December, 10.

Thakkar. Jitesh, Arun Kanda and Deshmukh, S. G. (2009). Supply chain management in SMEs: development of constructs and propositions. Asia Pacific Journal of Marketing and Logistics 20(1), pp. 1-13.

Thakkar. Jitesh, Arun Kanda, and Deshmukh, S. G. (2012). Supply chain issues in Indian manufacturing SMEs: insights from six case studies. Journal of Manufacturing Technology Management 23(5), pp. $634-664$.

Thoo AC, Z Sulaiman, SL Choi and Kohar, UHA. (2017). Understanding Supply Chain Management Practices for Small and Medium-Sized Enterprises. IOP Conf. Series: Materials Science and Engineering 215. doi:10.1088/1757-899X/215/1/012014

Ting J. S. K and Tsang A. H. C. (2012). Design of an RFIDbased Inventory Control and Management System: A case study. The West Indian Journal of Engineering 34(1-2), pp. 70-79. ISSN 0511-5728.

Udin., Zulkifli Mohamed, Mohammad K. Khan and Mohamed Zairi. (2006). A collaborative supply chain management. Business Process Management Journal 12(5), pp. 671-687.

Ulusoy G. (2003). An Assessment of Supply Chain and Innovation Management Practices in the Manufacturing Industries in Turkey. International Journal of Production Economics 86, pp. 251-270.

Usman. Said Abdullahi and Koseoglu. Ahmet Murat (2019). Practices and challenges of supply chain management between EU and Nigeria: A research on international trade. Journal of International Trade, Logistics and Law 5(2), pp. 1-9.

Valand Terje I., and Morten Heides, (2007). Can the SME survive the supply chain challenge? Supply Chain Management: An International Journal 12(1), pp. 2031.

Wisner, J.D., Tang, K.-C. \& Leong, G.K., (2016). Principles of Supply Chain Management: A balanced approach. 4th edn., Cengage Learning, Boston, MA.

Yang Yang, Fu Jia, Zhiduan Xu (2019). Towards an integrated conceptual model of supply chain learning: an extended resource-based view. Supply Chain Management: An International Journal 24(2), pp. 189214

Youqin, Pan., Ted Nam, Solomon Ogara and Seungsin Lee. (2013). Adoption model of mobile-enabled Systems in supply chain. Industrial Management \& Data Systems 113(2), pp. 171-189. DOI $10.1108 / 02635571311303523$.

Zhaofu Hong and Xiaolong Guo (2019). Green product supply chain contracts considering environmental responsibilities. Omega 83, pp. 155-166. https://doi.org/10.1016/j.omega.2018.02.010 

Dr. Ramakrishna Yanamandra is an Assistant Professor in Operations and Supply Chain Management in School of Business at Skyline University College, Sharjah, UAE. He possesses around twenty-five years of corporate and academic experience. He was a Manager-Operations in a leading Public Sector Undertaking, Govt. of India and managed large-scale projects related to production, operations and supply chain management involving conceptualization, planning and execution by interacting with all the stakeholders of the project. He holds a PhD in Supply Chain Management from Jawaharlal Nehru Technological University (JNTU), Hyderabad, India. He was successful in solving some of the challenging issues of supply chains in many projects which were handled by him. His research and teaching interests include Supply Chain Management, Operations Management, Lean Management, Total Quality Management, Six Sigma, Project Management, Healthcare Supply Chain and Service Operations Management. He has published several articles and book chapters in leading journals. He has successfully conducted many Executive Development Programmes (EDPs) and Management Development Programmes (MDPs) for various Government and Private sector enterprises in the area of Supply Chain Management and Six Sigma. 